\title{
Understanding the Determinants of Economic Integration in Latin America
}

\author{
Laura Márquez-Ramos \\ Institute for International Trade- University of Adelaide, Australia \\ Department of Economics and Instituto de Economía Internacional-Universitat Jaume I, Spain \\ Luis Marcelo Florensa \\ Instituto de Economía y Finanzas- Universidad Nacional de Córdoba, Argentina \\ María Luisa Recalde \\ Instituto de Economía y Finanzas- Universidad Nacional de Córdoba, Argentina
}

\begin{abstract}
When signing or enhancing trade agreements with Latin America, political and institutional factors play a more important role at present compared with their role in the past. In addition, a better institutional framework increases covered and legally enforceable provisions in Latin America trade agreements. This paper analyzes the determinants of economic integration in Latin America and the institutional quality of signed trade agreements with this region. By focusing on both a discrete choice and a linear framework, the study results prove that economic, geographic, institutional, and political factors influence economic integration. This is because these aspects are key elements in the formation and enhancement of trade agreements both within and outside Latin America. This study considers the role of additional exogenous political facts, such as the September 11 attacks in New York City, and the Revolución Bolivariana, a leftist movement in Venezuela, which affected economic integration in Latin America.
\end{abstract}

\footnotetext{
*Corresponding Author: Laura Márquez-Ramos; Institute for International Trade, University of Adelaide, Australia \& Department of Economics and Instituto de Economía Internacional, Universitat Jaume I, Campus del Riu Sec, 12071 Castellón de la Plana, Spain, Tel: + +34 964 728592, Fax: +34 964 728591, E-mail: lmarquez@eco.uji.es.

Co-Author: Luis Marcelo Florensa; Instituto de Economía y Finanzas, Universidad Nacional de Córdoba, Avenida Valparaíso S/N, Ciudad Universitaria, 5000 Córdoba, Argentina, Tel: +54351 4437300(Ex\# 48645), E-mail: florensa@eco.unc.edu.ar; María Luisa Recalde; Instituto de Economía y Finanzas, Universidad Nacional de Córdoba, Avenida Valparaíso S/N, Ciudad Universitaria, 5000 Córdoba, Argentina, Tel: +54351 4437300(Ext\# 48402), E-mail: lrecalde@eco.unc.edu.ar. 
JEL Classifications: F14, F15, F50

Keywords: Trade Agreements, Latin America, Institutional and Political Factors, Institutional Quality

\section{Introduction}

A better understanding of the determinants of economic integration is extremely important. This is crucial in the international arena, which faces a potential reversal in terms of the breadth and scope of economic integration. ${ }^{1}$ This paper contributes to the literature by providing insights on the causes of economic integration in Latin America (LA). LA represents an interesting case study because it is a region where the determinants of new regionalism ${ }^{2}$ might have been driven more by political and institutional factors than by geography. ${ }^{3}$

We analyze the importance of economic, geographic, institutional, and political factors in LA's economic integration from the perspectives of intra-LA as well as its relationship with the rest of the world. To do so, we consider several levels of economic integration, "shallow" versus "deep". We consider both non-reciprocal and preferential trade agreements as shallow Economic Integration Agreements (EIAs). Because of the region's particularities, ${ }^{4}$ we presume free trade agreements and customs unions as deep EIAs. In addition, we explore factors determining the institutional quality of signed trade agreements.

\footnotetext{
${ }^{1}$ A trade agreement reversal in Latin America occurred when Venezuela adopted a more rigid position regarding sovereignty than its partners in the Andean Community. The Community decided to coordinate its positions and to speak with a single voice in the Free Trade Area of the Americas (FTAA) negotiations, but Venezuela's decision to cooperate more closely with Mercosur led to a rupture with the Andean Community (see Nelson, 2013 for a better understanding of the institutional environment in Venezuela that eventually challenged the FTAA). More recent examples can be illustrated in other regions, such as Brexit or the withdrawal of the US from the Trans-Pacific Partnership.

${ }^{2}$ Márquez-Ramos et al. (2015) distinguished between "old" regionalism (until the late 1980s) and "new" regionalism, which the LA region implemented in the 1990s. Bown et al. (2017) used a similar distinction.

${ }^{3}$ As an example, in 2011, Chile, Colombia, Mexico, and Peru formed the Pacific Alliance, which has been recognized to be based more on policy affinity than on geography (The Economis 2016).

${ }^{4}$ In LA, a customs union represents the highest level of economic integration. For an analysis of further integration levels, see the study by Allegret and Sand-Zantman (2008), which discusses the feasibility of a monetary union between LA countries.
} 
Economic and geographic factors have determined the degree of regional integration in other economic regions (Magee 2003, Baier and Bergstrand 2004, Márquez-Ramos et al. 2011). However, when analyzing the formation and growth of economic integration in LA, political and institutional aspects should be considered given the degree of policy uncertainty in the region. Specifically, we investigate two additional exogenous political facts. It is due to the gaps between the European Union (EU) and the US regarding the attitudes toward the developing world. These divergences may have widened due to the attacks of September 11, 2001 (Grugel 2004). We analyze the impact of these events on US-LA EIAs. Futher, we consider the role of the Revolución Bolivariana, a leftist social and political movement in Venezuela led by Hugo Chávez. The Revolución Bolivariana nationalized private companies, included social welfare programs and opposed neoliberalism and policies of the International Monetary Fund (IMF) and the World Bank.

Our analysis confirms that geographic, economic, political, and institutional aspects are key elements in the formation and enhancement of EIAs as well as for high institutional quality of trade agreements that involve LA countries.

This paper is divided into six sections. Following the introduction in Section I, we present the background in Section II. Section III discusses the determinants of regional integration in the empirical analysis. Section IV describes the methodology and data. The empirical analysis is conducted in Section V, where we analyze what determines economic integration in LA, in addition to analyzing how economic decisions integrate LA countries with the rest of the world. Section VI presents the conclusion.

\section{Background}

The signing of an EIA often requires controversial decision making because EIAs generate global benefits that are usually distributed unequally between winners and losers. The delegation of power that derives from an integration agreement occurs at the expense of a loss of sovereignty of member countries and is usually accompanied by actions and commitments that may not be consistent with economic logic (Wyplosz 2006). Accordingly, economic integration processes may differ among developed and developing regions. To illustrate economic integration strategies in developed countries, 
although both the EU and the US promote economic liberalization, Europe is more explicitly concerned with politics and institution building than the US. Moreover, it endorses a North-South model of global cooperation, where the North assumes some responsibility for the development of the South (Grugel 2004). Concerning interactions among the EU, the US, and the rest of the world, Kohl et al. (2016) compared coverage and enforcement of 14 agreements involving the EU and 11 agreements involving the US. They found that the EU includes more legally unenforceable activities than the US, which focuses on a more limited range of legally enforceable commitments.

In the Western-sponsored international order, the best example of deep integration is the EU, the world's largest trading bloc and the most successful regional integrator (Doctor 2007). However, numerous issues such as Brexit, the globalization of the world economy, and increasing interdependence among countries have provoked intense discussions regarding economic integration. Many LA attempts to integrate regions have tried to follow the European model. However, experience suggests that European and LA integration strategies differ and that LA's commitment to provide deeper integration agreements is lower than that of European countries. In addition, unlike in Europe, LA governments do not want to cede sovereignty to a supranational body (see Schmitter 1970 and The Economist 2016).

Regionally, LA countries have suffered from great political and economic instability for decades. Furthermore, LA countries trade less with each other when compared with Asian or EU countries (see The Economist 2016 and 2017, Bown et al. 2017). Until very recently, two main integration axes could be distinguished in LA. ${ }^{5}$ On the one hand, the Pacific Axis has presented a continued strategy of free trade and trade agreements with rich and developed areas. ${ }^{6}$ On the other hand, the Atlantic Axis has presented an alternative strategy of regional integration, which meant protectionism and integration with other protectionist, primarily left-wing, governments in LA countries. ${ }^{7}$ Brazil offers a third possibility: trade among Brazil, Russia, India, China, and South Africa. Brazil, in particular, is a rising power that is fostering a hybrid order, characterized by deeper

\footnotetext{
${ }^{5}$ Some of the centre-right governments that recently came to power are keener to open trade than their left-wing predecessors (The Economist 2017). For example, it seems that nowadays, Brazil is interested in building bridges between Mercosur and the Pacific Axis; with the change of government in Argentina in December 2015, a new phase started with regard to trade policy and economic integration (Florensa et al. 2017).

${ }^{6}$ This first strategy joins Chile, Colombia, Mexico, and Peru, which are integrating with countries outside the region such as the US, the EU, and Asia (strategy of continuity).

${ }^{7}$ This second strategy includes countries such as Argentina, Bolivia, Ecuador, and Venezuela, which have less interest in global market integration (an alternative strategy).
} 
transnational integration (Stephen 2014). The commitment of highly heterogeneous member countries to economic integration in the region is naturally questioned (García de la Cruz and Sánchez Díez 2008, Florensa et al. 2015).

To illustrate this heterogeneity, Figure 1 and Figure 2 display tariff changes by country, distinguishing between countries in the Pacific and the Atlantic. Figure 1 displays higher tariff reductions for imports from Mercosur and the Latin American Integration Association (LAIA) in the Atlantic Axis.

Figure 2 illustrates higher tariff reductions for imports from developed countries in the

\section{Figure 1. Tariff reductions for imports in the Atlantic axis}

(1994 2008)



(Note) LAIA and NAFTA denote the Latin American Integration Association and the North American Free Trade Agreement, respectively. The figures are constructed with data of effectively applied tariffs (simple averages) coming from the world, NAFTA, EU, LAIA and Mercosur to reporting countries (Argentina, Bolivia, Ecuador, Venezuela) in year 1994 and 2008.

(Source) Authors' own elaboration, with tariff data obtained from the World Integrated Trade Solution. 
Pacific Axis. Chile has undergone the most far-reaching liberalization process. Mexico experienced greater liberalization with other EIAs that trade with developed countries by joining the North American Free Trade Agreement (NAFTA) and signing a free trade agreement with the EU in 2000. Meanwhile, the remaining countries (excluding Chile and Mexico) have liberalized trade with the LAIA and Mercosur. Compared with the Atlantic Axis, countries in the Pacific Axis show lower global import tariff rates, including imports from NAFTA and the EU. It seems that countries following a continuity strategy are more advanced in worldwide trade integration and tariff

\section{Figure 2. Tariff reductions for imports in the Pacific axis}

(1994 2008)

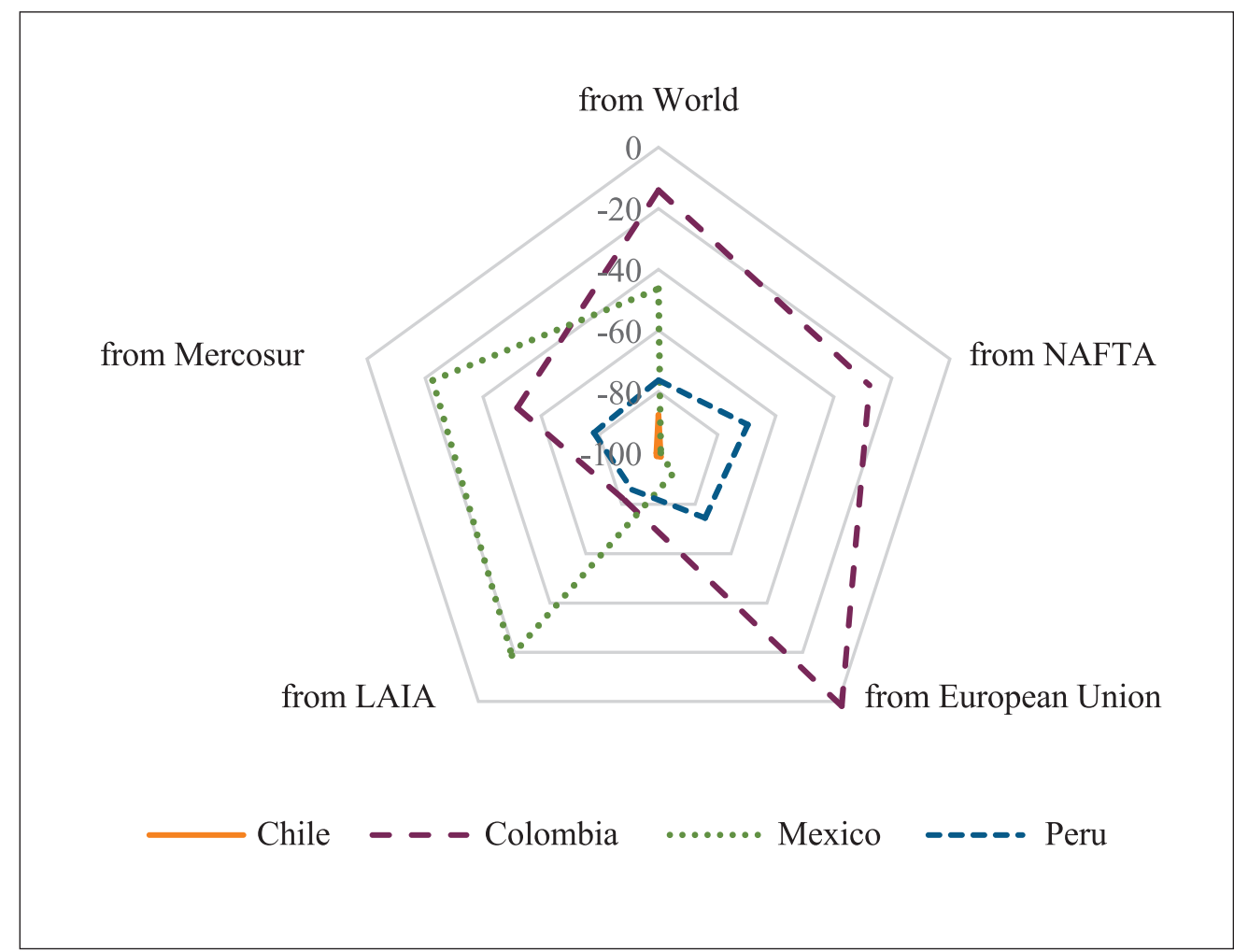

(Note) Tariff changes in Chile range between $-87.35 \%$ and $-99.27 \%$. Therefore, they cannot be appreciated given the scale of this figure. LAIA and NAFTA denote the Latin American Integration Association and the North American Free Trade Agreement, respectively. The figures are constructed with data of effectively applied tariffs (simple averages) coming from the world, NAFTA, EU, LAIA and Mercosur to reporting countries (Chile, Colombia, Mexico, Peru) in year 1994 and 2008.

(Source) Authors' own elaboration, with tariff data obtained from the World Integrated Trade Solution. 
concessions. In contrast, countries with alternative strategies seem to be less ambitious regarding trade integration, favoring their own national policies and tariff concessions to LA partners.

Integration strategies in LA countries have changed over the last 50 years, and slow recent progress in multilateral talks has sparked regional integration. These changes have emphasized significant events, such as the restructuring of the original Andean Group into the Andean Community of Nations and the bilateral integration process between Argentina and Brazil, with special emphasis on the automotive and other sectors. These changes have also included the creation of Mercosur, the free trade agreement between Mexico and North America (NAFTA), and signing of bilateral preferential trade agreements with countries around the world, such as the US and EU members (Peña 2011).

In recent years, there has been a clear trend in LA to review concepts, objectives, and methodologies concerning the development of regional integration. Currently, LA countries have multiple options in their strategies to participate in the world economy. Institutional environments with overlapping functions and powers have proliferated (Peña 2010). This overlap might reverse LA economic integration since increased irreversibility would have sustained well-established trade agreements and would have made new trade agreements more difficult to achieve (Chisik 2003).

\section{The Determinants of Economic Integration}

Baier and Berstrand (2004) used a qualitative choice model to provide one of the first empirical analyses of free trade agreement determinants. Previously, Magee (2003) showed that countries are more likely to sign an EIA if they have significant bilateral trade, similar capital-labor ratios, and both are democracies. Importantly, Magee (2003) estimated when the formation of a preferential trade agreement is modeled as an endogenous choice.

Mansfield et al. (2002) found that democratic countries are more likely to enter into an EIA. We test the hypothesis that the probability of two countries signing an integration agreement depends on their political regimes, democratic versus autocratic.

Vicard (2012) found that trade and institutional security issues interact in the 
formation of EIAs. Vicard's (2012) results indicated that countries more open to disputes and trade are more likely to create the most meaningful regional agreements. Malamud and Schmitter (2006) analyzed different integration theories to explain integration processes in Europe and elsewhere in the world. These authors critically reflected on lessons learned from the EU about other forms of economic integration, such as the Mercosur. Several lessons that Malamud and Schmitter (2006) considered to be transferrable are as follows: a) integration requires that member countries be democratic; b) regional integration arises from a convergence of interests and not by the creation of an identity; c) integration encompasses nations of different sizes, levels of development, and power but requires leadership; d) integration can be peaceful and voluntary but not always without conflict; e) integration should begin with a small number of member countries but be open to additional countries; and f) integration may experience excessive institutionalization or an institutional deficit.

Although policies may be structured toward similar development objectives in LA economies (see b) above), LA countries are heterogeneous and follow different trade integration strategies. In addition, given the high degree of policy uncertainty in LA, it is worth analyzing whether regional integration processes both inside and outside LA may be driven by political and institutional factors, together with "traditional" factors such as geography and the economy (Baier and Bergstrand 2004).

The study by Márquez-Ramos et al. (2011) is most similar to ours because it investigated the determinants of EIAs by considering not only geographical and economic factors but also sociopolitical variables as the main causes of EIA formation and enhancement. According to the results, although economic and geographical variables appear to be the most important determinants in forming shallow EIAs, institutional and sociopolitical factors are more important in explaining deep integration processes. They found that countries in the same continent are more likely to establish higher economic integration. Their model is more accurate when institutional and sociopolitical variables are included in the regressions to explain the formation and deepening of EIAs.

Following previous empirical research (Baier and Bergstrand 2004) and concerning economic and geographical variables, we first expect that the larger the economies of the trading countries, the greater the probability of EIA formation or enhancement. Accordingly, $R G D P$ measures the sum of real GDPs in the natural log terms. The parameter associated with this variable is expected to be positive. Second, the more similar each countries' economic size, the higher the probability of EIA formation or 
enhancement. $D R G D P$ is the absolute value of the difference between the logs of the real GDPs of countries $i$ and $j$, and the associated parameter is expected to be negative. Third, we render that two countries will more likely form or enhance an EIA when the distance between them is less. We specify the distance variable as in the study by Baier and Bergstrand (2004). This variable, called NATURAL, is defined as the logarithm of the inverse of the distance between trading partners. The parameter associated with this variable is expected to be positive. Fourth, we conjecture that the probability of EIA formation or enhancement increases as the geographic remoteness of a country or pair of countries rises. This study constructs the same remoteness variable (REMOTE) used by Baier and Bergstrand (2004). When a country is relatively far from its trading partners, it trades more bilaterally with its neighbors, thereby increasing the probability of EIA formation. The reasonable sign of the associated parameter is positive. Additionally, we consider whether trading partners are adjacent $(A D J)$, landlocked $(L A N D)$, and whether they speak a common language $(L A N G)$. We expect a positive sign for the parameter associated with these variables.

Regarding institutional and political factors, we expect that more democratic countries are more likely to form or enhance an EIA in LA. We use a variable (POLITY2) that takes a higher value for democratic countries and a lower value for autocratic countries. We think that this variable to have a positive effect on the dependent variable. Regarding political rights' effect on EIAs formation or enhancement, we utilize an index that grows with fewer political rights $\left(P_{-}\right.$RIGHTS). We presume this variable to have a negative effect on the dependent variable. In other words, we envision that democratic LA countries are more likely to form (and "enhance") economic integration agreements. Countries with fewer political rights are less likely to form or enhance agreements. Because they capture different mechanisms, variables that capture these two effects will be simultaneously included in the regressions. At the beginning of the period analyzed, more nondemocratic regimes existed in LA. In the most recent period analyzed, in contrast, LA countries are democracies. Once a country's democracy has been consolidated, it is important that the democratic regime is accompanied by numerous reforms that promote the proper functioning of institutions. The simultaneous inclusion of these two variables (POLITY2 and P_RIGHTS) in the empirical analysis allows the consideration of both the importance of creating democratic regimes and the process of democratic consolidation as a requirement for countries' integration into the world.

Finally, we analyze the effect of trade policy on economic integration processes. Specifically, we consider the effect of trade flows (TRADE), the Intensive Margin (IM) 
of trade, and the Extensive Margin (EM) of trade on EIAs' formation and enhancement. As in the study by Márquez-Ramos et al. (2011), we expect TRADE to have a positive effect on the dependent variable. To our knowledge, this is the first time that the effect of IM and EM on EIAs' formation and enhancement has been analyzed. In the same way that maintaining and enhancing trade relations over time (the IM of trade) or the appearance of new products (the EM of trade) increases a country's exports (Florensa et al. 2015), the EM or the IM may have a role in the process of economic integration.

Márquez-Ramos et al. (2015) noted the time evolution of the EM and IM in a number of LA countries, showing that both evolved divergently. For example, they showed that the highest IM values occurred during the second half of the 1980s, with the IM decreasing after the LA economic crises at the beginning of the present century. The EM seems to have increased considerably since 2001.

\section{Methodology and Data}

As a first step, we explain why two countries enter into an EIA and why they would want to expand this agreement. The empirical background must provide an analysis to effectively model decisions. Therefore, we estimate an ordered logit wherein the dependent variable is the level of economic integration among countries. When a country enters into a bilateral trade agreement, its next decision may be whether to deepen its level of integration. Therefore, we model a series of binary decisions, where each decision either accepts the current integration level or advances it to a higher level.

The econometric model is constructed as follows. An ordinal variable $Y$ is a function of an unobserved continuous variable $Y^{*}$, which has many threshold points that determine the values that the discrete observable variable $Y$ can assume.

We distinguish the following four types of trade agreements between each pair of countries $i$ and $j$ : Nonreciprocal Preferential Trade Agreements (NRPTA), Preferential Trade Agreements (PTA), Free Trade Agreements (FTA), and Customs Unions (CU). This mandates four threshold points: Threshold 1 implies that two countries $(i$ and $j$ ) engage in a NRPTA, Threshold 2 implies a PTA, Threshold 3 implies an FTA, and Threshold 4 represents a CU. 


$$
\begin{gathered}
Y_{i j}=0 \text { if } Y_{i j}^{*} \leq \delta_{1} ; Y_{i j}=1 \text { if } \delta_{1} \leq Y_{i j}^{*} \leq \delta_{2} ; Y_{i j}=2 \text { if } \delta_{2} \leq Y_{i j}^{*} \leq \delta_{3} ; \\
Y_{i j}=3 \text { if } \delta_{3} \leq Y_{i j}^{*} \leq \delta_{4} ; Y_{i j}=4 \text { if } Y_{i j}^{*} \geq \delta_{4}
\end{gathered}
$$

The probability model assumes that $Y_{i j}^{*}$ is as follows:

$$
Y_{i j}^{*}=\sum_{k=1}^{r} \beta_{k} X_{i j k}+\varepsilon_{i j,}
$$

where $X_{i j k} k=1, \ldots, r$ are the covariates, and $\varepsilon_{i j}$ is the random term with logistic distribution.

We base our calculations for bilateral trade from 1962 to 2009 on the dataset provided by Feenstra et al. (2005), which we complement with data from the World Integrated Trade Solution. The intensive and extensive margins are computed as described by Florensa et al. (2015) and Márquez-Ramos et al. (2015). Trade agreements used to construct the dependent variable $(E I A),{ }^{8}$ which take many different forms, are summarized in the study by Florensa et al. (2015).

Our dataset includes exports from 11 LAIA countries (Argentina, Bolivia, Brazil, Chile, Colombia, Ecuador, Mexico, Peru, Paraguay, Venezuela, and Uruguay) to 161 destination countries. We add several variables to this dataset. In particular, we consider the factors of geography, economy. politics and institutions, and common language as control variables for all 11 LAIA countries and 161 trading partners.

In addition to the discrete variable considered as a dependent variable, heterogeneity of trade agreements is considered in the second step. Kohl et al. (2016) developed several publicly available indices $(I C, E I$, and $I I Q)$ to measure trade agreements' heterogeneity, which we use in this study. Specifically, Kohl et al. (2016) considered "WTO" and "WTO ${ }^{\mathrm{X}}$ " provisions to construct the indices IC (index for the number of WTO provisions covered by an agreement) and IE (index for the number of WTO provisions legally enforceable by an agreement). Provisions that confirm countries' existing multilateral obligations and that also may deepen such commitments are categorized as $\mathrm{WTO}^{+}$ provisions. Examples of $\mathrm{WTO}^{+}$provisions are measures on anti-dumping, restrictions on state aid, and the liberalization of trade in services. "WTO ${ }^{\mathrm{X}}$ " provisions involve policy domains not covered by the WTO's current mandate and may compromise the WTO's ability to expand into these legal territories with binding, nondiscriminatory policies.

\footnotetext{
${ }^{8}$ Data is available at http://www3.nd.edu/ jbergstr/ and on the website of the World Trade Organization (WTO). See Florensa et al. (2015).
} 
Examples range from anti-terrorism to environmental and labor market regulations. Additionally, Kohl et al. (2016) constructed an index that reflects an agreement's Institutional Quality (IIQ), which measures a trade agreement's depth by its number of provisions. Provisions in this indicator are in relation to consultations, definitions, dispute settlements, duration and termination, evolutionary mechanisms, institutional frameworks, objectives, plans and schedules, and transparency of trade agreements.

The data and variables used in this research come from different statistical sources that are listed in the Appendix, together with the expected sign of the estimated coefficient associated with each variable (see Appendix 1).

In the empirical analysis, we first examine the determinants of LA's regional integration between 1962 and 2009. As the second step, we use the indices computed by Kohl et al. (2016) as Left-Hand-Side (LHS) variables to analyze the determinants of trade agreements' institutional quality and the number of provisions covered and enforceable by LA integration agreements in Ordinary Least Squares (OLS) regressions.

Notably, a way of validating the results obtained is to observe whether they are robust for the different models, different specifications, and estimation techniques used. Numerous versions of the proposed model are estimated. We apply both maximum likelihood and OLS estimation techniques and rely on two types of LHS: a discrete 0 4 dependent variable and a continuous variable that measures trade agreements' heterogeneity more completely.

\section{Empirical Analysis}

\section{A. The dynamics of economic integration in LA}

We use our panel dataset that covers the period 1962 2009 to analyze the effect of geographical, economic, institutional, and political factors on economic integration in LA. In addition, we consider two additional exogenous political issues as determinants of EIA formation and enhancement. First, because the EU and the US present distinctive models of governance toward the developing world and because these divergences may have widened following the attacks of September 11, 2001 (Grugel 2004), we analyze the role of these events in US-LA EIAs with a dummy $11 S$, which takes the value 1 if the 
trading partner is the US from the year 2001 forward and 0 otherwise.

Second, we consider the role of the policy's affinity with the Revolución Bolivariana, which may contribute to the two main strategies of regionalism: the strategy of continuity in Chile, Colombia, Mexico, and Peru and the alternative strategy followed in Argentina, Bolivia, Ecuador, and Venezuela. Therefore, we introduce four additional dummy variables: one for Argentina from 2005, one for Bolivia from 2006, one for Ecuador from 2007, and one for Venezuela from 1999 (see notes below in Table 1).

Ordered logit estimates ${ }^{9}$ are presented in Table 1. We run five specifications (Model 1 Model 5) that alternatively include the trade policy variables and the dummy variables, capturing the effects of September 11 attacks and the Revolución Bolivariana.

Model 1 shows the results of our baseline model, with economic, geographical, political, and institutional variables. In Model 2, we add the trade variable. Models 3-5 show the most complete specifications, which include the (lagged) EIA, (lagged) intensive and extensive margins (IM and EM), the dummy $11 S$ (Model 3), and the dummies for Argentina, Bolivia, Ecuador, and Venezuela (Model 4), in addition to the variables considered in previous models. Finally, these dummy variables are included in the same regression (Model 5).

Table 1 displays that economic and geographical variables, political rights, and the variable POLITY2 have the expected sign and are statistically significant. This means that both the level of political rights and the extent of democratic practices positively affected the signing or enhancing of EIAs between 1962 and 2009. With regard to trade policy, Trade, IM, EM, and EIA variables are statistically significant, and the associated estimated coefficients present the expected positive sign.

Concerning exogenous political events, the coefficient of the dummy $11 \mathrm{~S}$ is negative and statistically significant Model 3 and Model 5. This means that the September 11 terrorist attack on the US soil negatively affected the likelihood of establishing or deepening EIAs between the US and LA countries. Models 4 and 5 show that policy affinity with the Revolución Bolivariana ideology presents different consequences in terms of economic integration. Thus, the estimated coefficient for the Argentina dummy is negative and significant, whereas the estimated coefficients for the Bolivia and Ecuador dummies are positive and significant. The coefficient is not statistically significant only for Venezuela.

Since the revolution in Venezuela lacked a commitment to democracy (Molina

\footnotetext{
${ }^{9}$ To carry out this analysis, we use (temporary) lagged explanatory variables for those regressors that are potentially endogenous in line with the previous related literature.
} 


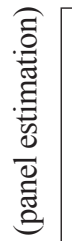

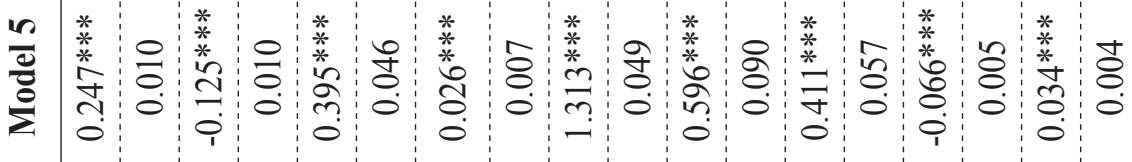

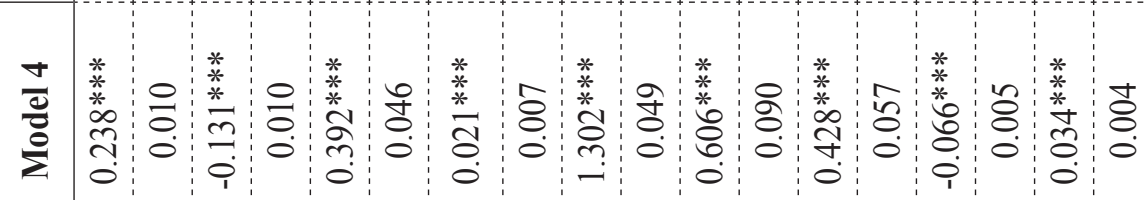

葛



葛

.

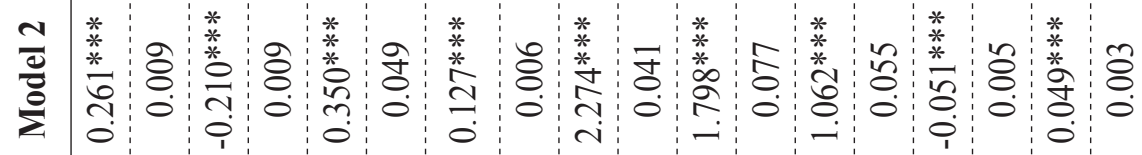

ט..

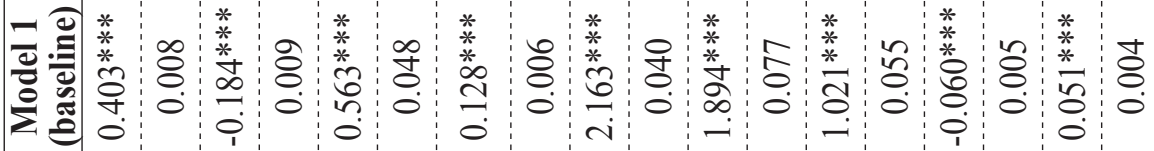

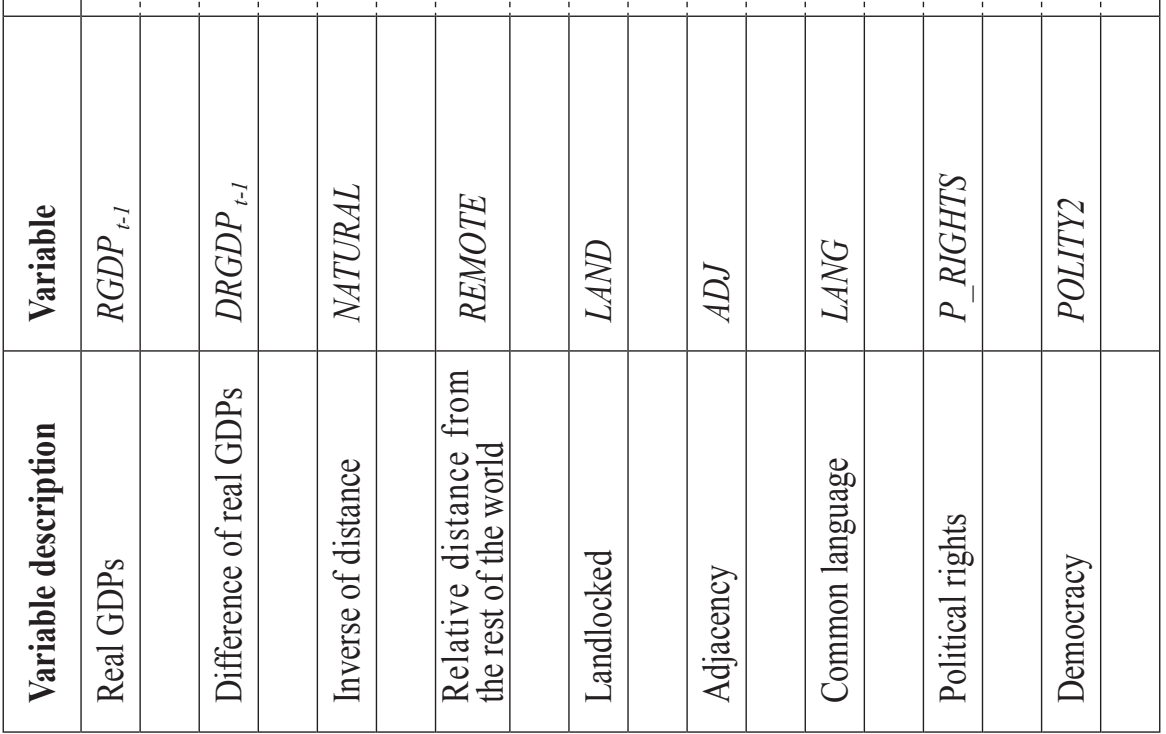




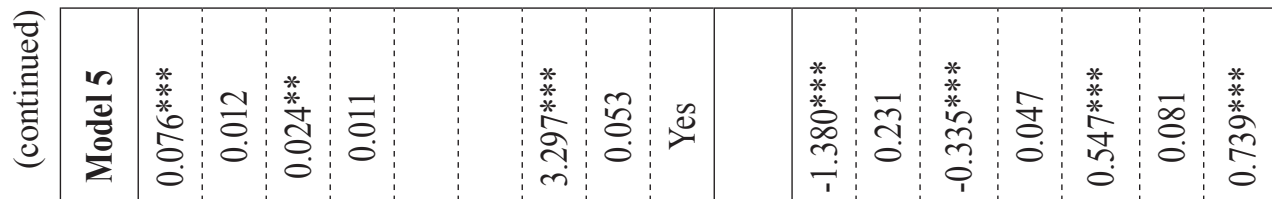



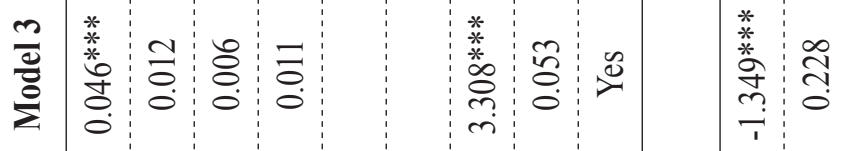

章善



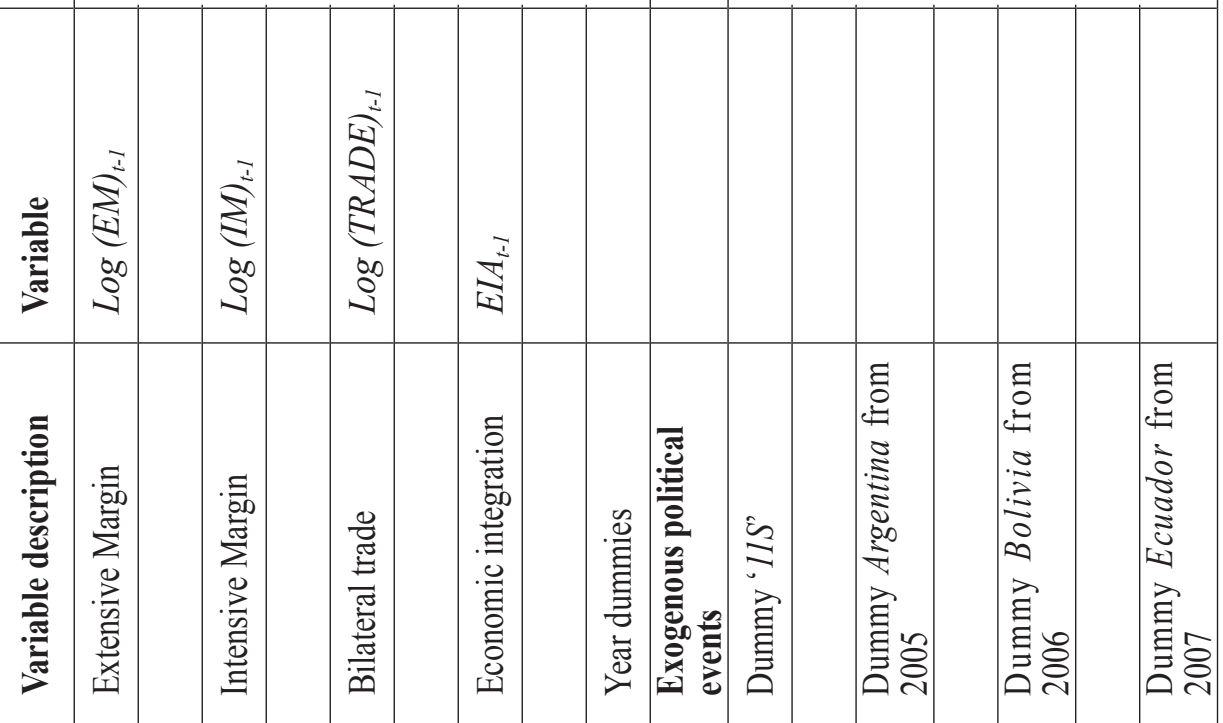




\begin{tabular}{|c|c|c|c|c|c|c|c|c|c|c|c|c|c|c|}
\hline$\frac{n}{\frac{0}{0}}$ & ర్రి & $\begin{array}{l}\text { + } \\
\text { O! } \\
\dot{0}\end{array}$ & $\stackrel{?}{0}$ & $\begin{array}{l}\stackrel{\infty}{N} \\
\stackrel{n}{0} \\
0\end{array}$ & $\begin{array}{l}\approx \\
\tilde{\sigma} \\
0\end{array}$ & $\begin{array}{l}\vec{B} \\
\dot{ \pm}\end{array}$ & $\underset{0}{\mathbb{J}}$ & $\begin{array}{l}\stackrel{ }{2} \\
\text { 응 }\end{array}$ & $\begin{array}{l}\overline{0} \\
\stackrel{0}{0}\end{array}$ & $\begin{array}{l}\tilde{J} \\
\infty \\
\stackrel{\sigma}{=}\end{array}$ & $\begin{array}{l}\text { to } \\
0 \\
0\end{array}$ & 守 & 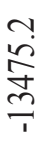 & $\frac{\curvearrowleft}{\stackrel{n}{2}}$ \\
\hline$\frac{ \pm}{\frac{ \pm}{\tilde{D}}}$ & 훙 & $\begin{array}{l}0 \\
0 \\
0 \\
0\end{array}$ & $\stackrel{?}{0}$ & $\begin{array}{l}\infty \\
\stackrel{8}{0} \\
\dot{0}\end{array}$ & $\begin{array}{l}\text { ठై } \\
\text { ठै. }\end{array}$ & $\begin{array}{l}\vec{\Xi} \\
\pm\end{array}$ & 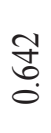 & సે & \begin{tabular}{l}
$\infty$ \\
\multirow{6}{6}{} \\
0 \\
0
\end{tabular} & 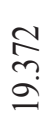 & $\begin{array}{l}\overline{8} \\
\stackrel{0}{0}\end{array}$ & 京 &  & $\frac{n}{2}$ \\
\hline$\frac{\infty}{\frac{\pi}{0}}$ & & & & $\begin{array}{l}\hat{\sigma} \\
\infty \\
\infty\end{array}$ & $\stackrel{n}{n}$ & $\begin{array}{l}\tilde{2} \\
\tilde{n}\end{array}$ & $\begin{array}{l}\infty \\
\infty \\
? \\
0\end{array}$ & $\begin{array}{l}\text { \& } \\
\text { ơ } \\
0\end{array}$ & $\begin{array}{l}\overrightarrow{8} \\
\stackrel{0}{\circ}\end{array}$ & $\begin{array}{l}\stackrel{n}{\sim} \\
\infty \\
\infty\end{array}$ & $\begin{array}{l}0 \\
0 \\
0 \\
0\end{array}$ & $\begin{array}{l}\infty \\
\stackrel{\infty}{+} \\
0\end{array}$ & $\begin{array}{l}\hat{a} \\
\text { à } \\
\stackrel{n}{n}\end{array}$ & $\frac{\curvearrowleft}{\stackrel{n}{\approx}}$ \\
\hline$\frac{N}{\frac{N}{0}}$ & & & & $\begin{array}{l}+ \\
0 \\
0 \\
\text { i }\end{array}$ & 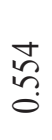 & $\stackrel{+}{\stackrel{+}{ \pm}}$ & $\begin{array}{l}\stackrel{+}{n} \\
? \\
0\end{array}$ & $\begin{array}{l}\check{7} \\
\stackrel{7}{0}\end{array}$ & $\frac{n}{n}$ & $\begin{array}{l}\varrho \\
0 \\
\infty\end{array}$ & \begin{tabular}{l}
$\infty$ \\
$n$ \\
\hdashline
\end{tabular} & $\begin{array}{l}\text { oे } \\
\text { กิ }\end{array}$ & $\begin{array}{l}\overrightarrow{3} \\
\stackrel{2}{\sigma} \\
\stackrel{5}{?}\end{array}$ & $\begin{array}{l}\underset{\Xi}{\Xi} \\
\overparen{Z}\end{array}$ \\
\hline
\end{tabular}

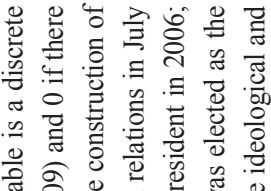



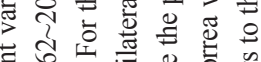

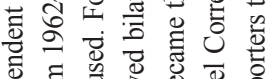


F

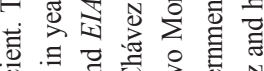



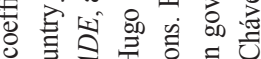

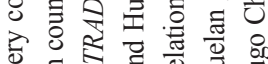

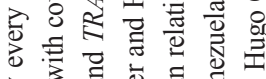

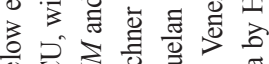

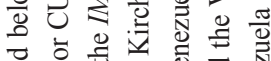

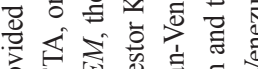

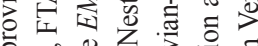

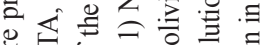

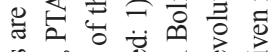

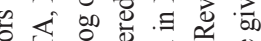

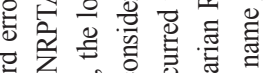


卷 \%

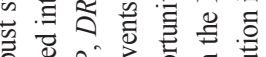

\begin{tabular}{|c|c|c|c|c|c|c|c|c|c|c|}
\hline  & 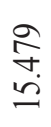 & $\begin{array}{l}\text { హె } \\
? \\
0\end{array}$ & $\begin{array}{l}\infty \\
\infty \\
\infty \\
\end{array}$ & $\begin{array}{l}3 \\
? \\
?\end{array}$ & $\begin{array}{l}\bar{\Omega} \\
2\end{array}$ & $\begin{array}{l}\stackrel{0}{\circ} \\
?\end{array}$ & $\stackrel{\widetilde{n}}{\stackrel{\sim}{\sim}}$ & $\begin{array}{l}\overline{0} \\
n \\
0\end{array}$ & $\stackrel{n}{\tilde{0}}$ & 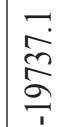 \\
\hline
\end{tabular}
兽过

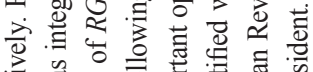

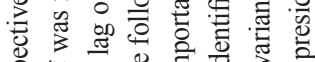
क्षे 응



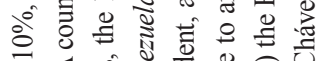



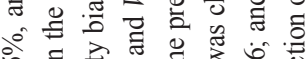

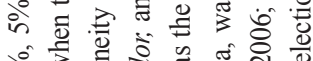

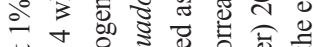

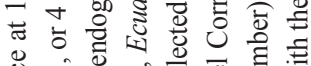

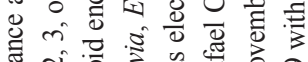



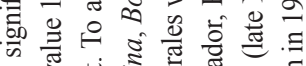

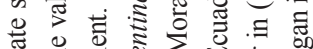

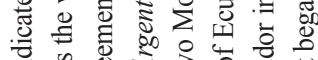

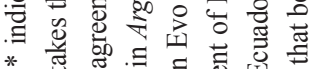

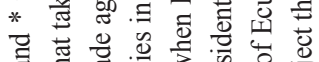



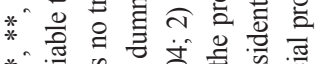

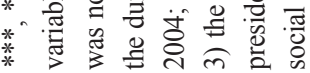
¿ 
2003), the political and institutional variables included in the regression might partially capture the exogenous effect of Venezuela's Revolución Bolivariana. The dummies for Ecuador from 2007 and for Bolivia from 2006 positively correlate with the likelihood of signing new trade agreements or enhancing existing trade agreements. However, because the last year in our sample is 2009, further implications from the study's results should be taken with caution. The obtained results are in line with the fact that Argentina could have been implementing economic policies that negatively affected the probability of signing and enhancing EIAs with third-party countries. For example, although participation in production networks increases trade flows, many implemented strategies in Argentina were seeking to balance trade and increase the use of local components in domestic industries, such as automobiles (Márquez-Ramos 2016). Orefice and Rocha (2014) suggested that governments should reconcile their divergent domestic practices to strengthen and secure production network activities across countries. The implementation of interventionist industrial policy, which includes tools such as strategic trade and investment policies, is distinctive from that of the liberal West (McNally 2013, Stephen 2014). This interpretation should be taken with caution because although we have already controlled for potential factors that the previous literature has shown to be relevant determinants of EIAs' formation and enhancement in a discrete choice framework (Baier et al. 2004, Márquez-Ramos et al. 2011), we find that the dummy for Argentina is negatively correlated with the dependent variable, not with specific Argentinean policies.

\section{B. The determinants of institutional quality in LA}

We assess what determines higher institutional quality of negotiated trade agreements, in addition to higher coverage and enforcement of provisions in LA regional integration. To do so, we perform a cross-sectional analysis for the years 1998 and 2009. ${ }^{10}$

We append to our cross-sections for 1998 and $2009^{11}$ and consider trade agreements that were enforced until 1998 and 2009, using three variables for each agreement.

\footnotetext{
${ }^{10}$ While a positive investment climate existed at the beginning of Mercosur, it changed because of several LA economic crises after 2000 , with political instability and uncertain property rights exacerbating a downward trend. In the mid-1990s, states considered using open regionalism strategies to additional regions to respond to the challenge of deeper integration in the global economy, ameliorate the impacts of globalization, and create a more secure multilateral order (Doctor 2007). The two cross-sections that we examine represent the period before and after the respective LA crises in 1998 and 2009.

${ }^{11}$ As in the panel analysis, it is worth mentioning the endogeneity issue, as some covariates might be correlated with the error term. Specifically, a trade agreement formed several years prior to 1998/2009 likely influenced subsequent economic growth, incomes, trade, and capital stocks in 1998/2009, then these variables may be endogenous. To account for this, we use the earliest available data to construct lagged regressors.
} 
Then, we run different cross-sectional regressions for 1998 and 2009 using OLS, with these three variables as LHS variables: (1) IIQ (the index that reflects an agreement's institutional quality); (2) IC (the index for the number of WTO provisions covered by an agreement); and (3) IE (the index for the number of WTO provisions legally enforceable in an agreement).

In LA, some countries have more than one signed agreement. For example, Argentina and Bolivia have signed three agreements. Both have been LAIA members since 1981, with an IE index of $0.20 .^{12}$ With an IE index of 0.39 , Bolivia signed a treaty with Mercosur in 1997 and signed another treaty as a member of the Andean Community in 1998 (with an index of 0.27). If a pair of countries are signatories to more than one agreement, we take the higher integration figure.

Our regression results are displayed in Table $2 .^{13}$ These results show that the institutional quality of a regional agreement between two countries increases if a deeper EIA existed (see Model 6 for 1998, and Model 9 for 2009). Trade margins are not statistically significant. The variable POLITY2 is positive and significant for 2009 because a better political scenario significantly increases provisions that are covered and legally enforceable in signed trade agreements.

The obtained results also prove that economic, geographic, and language variables are significant in both years. However, natural and landlocked variables are not statistically significant.

\footnotetext{
${ }^{12}$ This index represents the number of WTO provisions legally enforceable in an agreement. Further, 0 means minimum integration, and 1 means maximum integration.

${ }^{13}$ Note that in the cross-section regressions, we include among the Right-Hand-Side (RHS) variables the absolute differences in the capital stock per worker ratio (DKL) as a proxy for relative factor endowment differences (traditional trade models suggest that the benefits of an EIA increase the wider their relative factor endowments). This variable was not included in pooled ordered logit specifications because of data availability. The expected sign of the parameter associated to this variable is positive.
} 


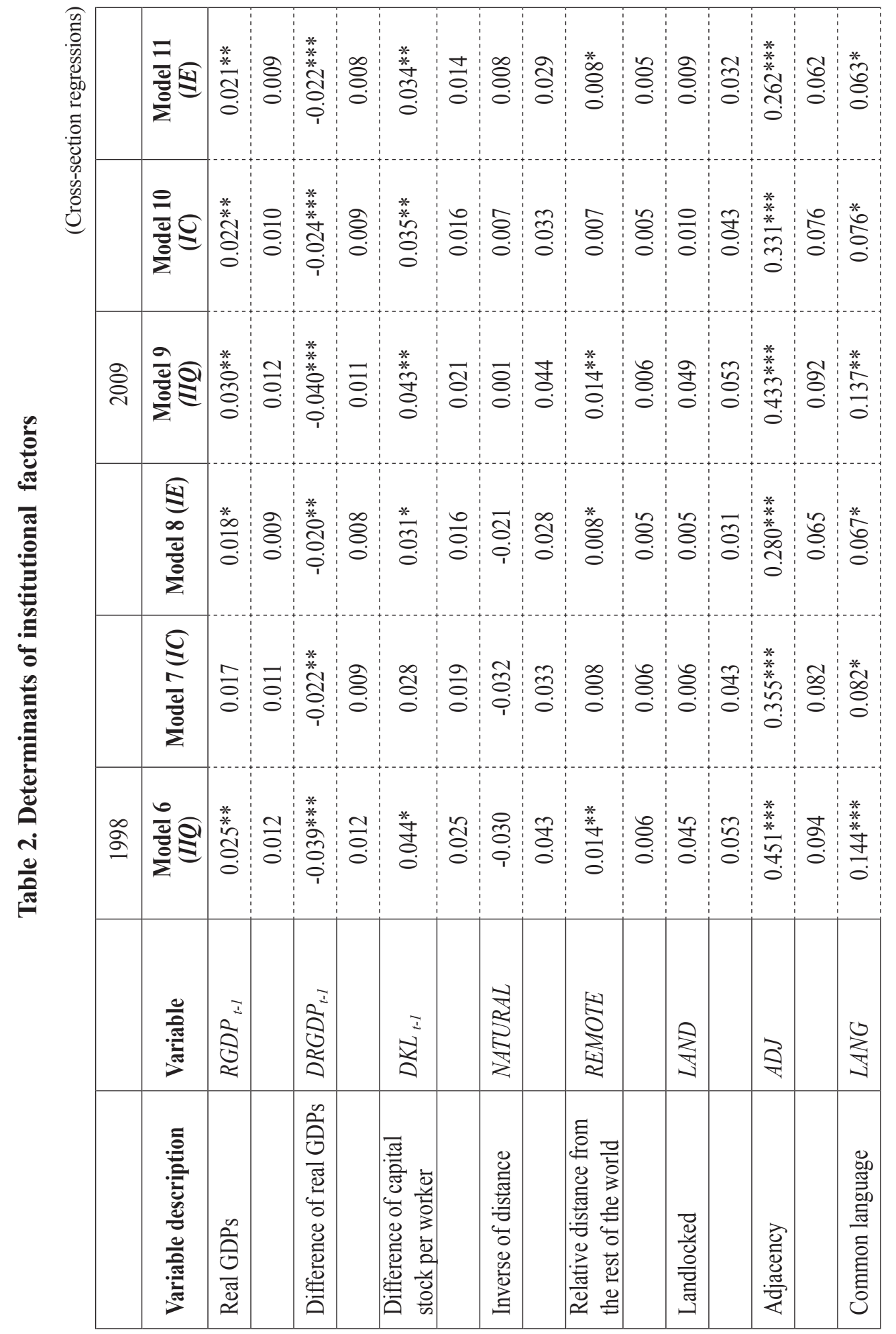




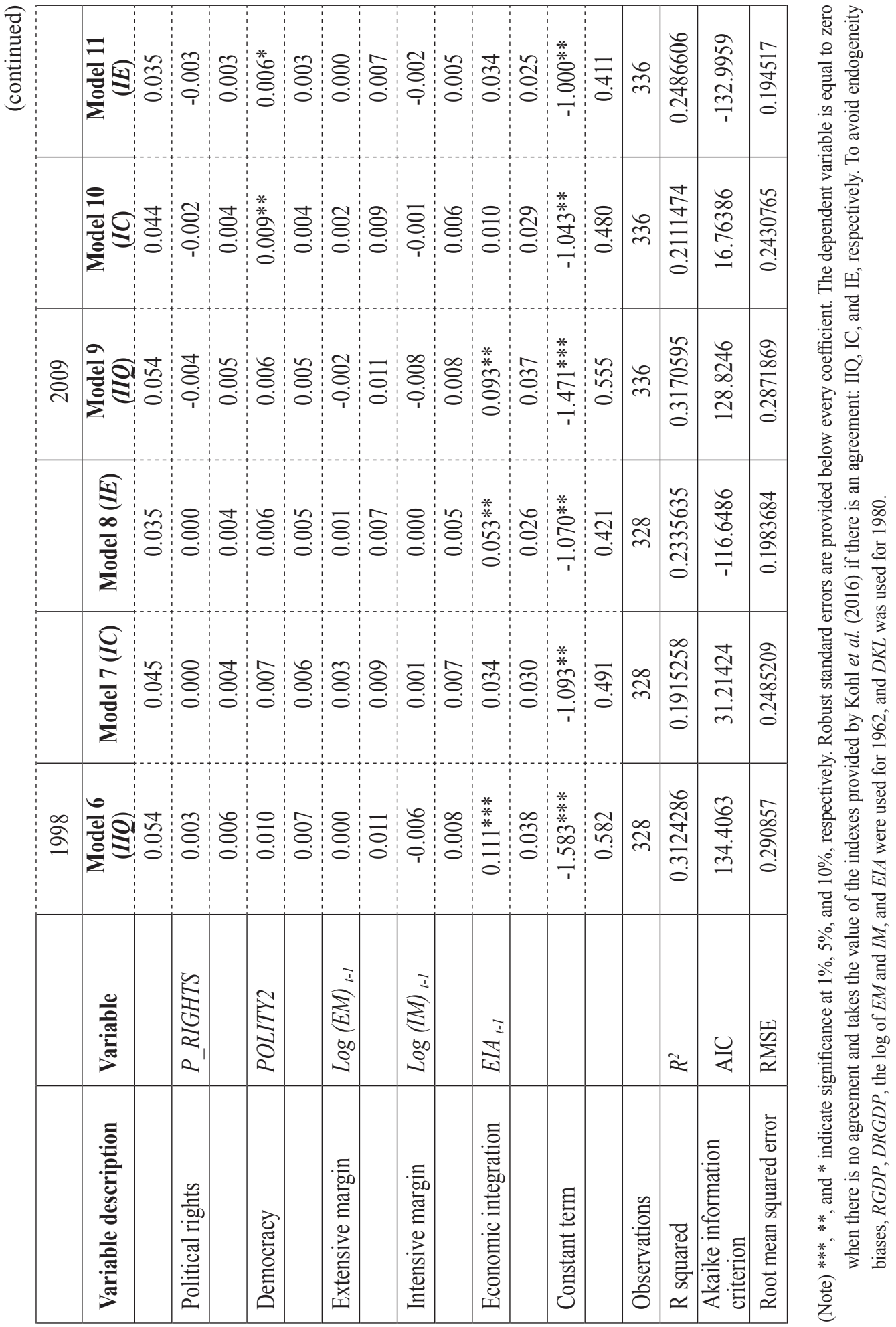




\section{Robustness}

We perform four robustness checks. First, we test whether the results obtained for the dummy $11 S$ are consistent by running several regressions that differ for the last sample year. Then, we estimate regressions for the periods 1962 2002, 1962 2003, and 1962 2004, and so on. Obtained results validate that the coefficient for the dummy $11 S$ is always negative and statistically significant.

Second, we run regressions on the dynamics of economic integration, considering only reciprocal (i.e., negotiated) trade agreements. ${ }^{14}$ Obtained results confirm that economic, geographical, political, and institutional factors are important determinants for the creation and enhancement of existing negotiated trade agreements.

As a third robustness check, we identify one variable that captures part of the existing heterogeneity between LA countries discussed above to avoid the use of dummies included for different countries in various years. Specifically, we use the foreign value embodied in domestic final demand (see Appendix 1, variable WIO), which allows us to capture the heterogeneity present in LA countries' demand for imported goods. ${ }^{15} \mathrm{We}$ therefore run two ordered logit cross-sectional regressions, considering only negotiated trade agreements for the years 1998 and 2009. For the 1998 regression, we find that the added foreign value embodied in domestic final demand is positive and significant for the trade agreements at a $10 \%$ level of significance. This variable is not statistically significant in 2009. These results suggest that in the period before the LA crises, participation in the world economy measured as the value added of inputs arriving from abroad was, overall, relevant for explaining the creation and enhancement of trade agreements. After the LA crises, the start of the Revolución Bolivariana and the terrorist attacks of September 11, 2001, this issue was not relevant for explaining LA economic integration. This result corroborates the increasing role of political and institutional factors in LA economic integration.

As a final robustness check, we include fixed effects for LA counterparts in the OLS regressions to further consider the potential problem of endogeneity in our variables

\footnotetext{
${ }^{14}$ We consider that NRPTAs are not trade agreements because these agreements are, in fact, not negotiated. Instead, "donor countries" offer a program where various countries can export under tariffs lower than those in the MFN. However, since this offer is unilateral, the receiving country does not have a say in its design. In addition, "donor countries" did not differentiate non-reciprocal trade preferences between developing countries until the early 2000s, so political factors might not have influenced which countries were offered such (non-reciprocal) preferences. In contrast, PTAs, FTAs, and CUs are negotiated, and all involved parties must be in agreement. Therefore, because NRPTAs (as an "earlier" form of agreement) only contain inputs from one country, other LA countries then might choose a PTA at a later stage of negotiation. In other words, an NPTA, versus a PTA, FTA, or CU, represents two different forms of decisions.

${ }^{15}$ One shortcoming of using this variable is that data exists for only five LA countries: Argentina, Brazil, Chile, Colombia, and Mexico. Thus, the number of observations is considerably reduced.
} 
of interest, which might arise because of the omitted variables that characterize LA countries. Similar results are obtained using these fixed effects, which also indicate that economic and geographical factors are important to explain why LA countries sign trade integration agreements of higher institutional quality. In addition, political and institutional factors seem to play a role in the number of covered and enforceable provisions in LA trade agreements in the most recent period.

\section{Policy Implications}

The causes and consequences of economic integration in LA are especially relevant in terms of trade policy. Economic integration fosters international trade, which in turn stimulates countries' economic growth. Recently, Bown et al. (2017) suggested a revitalized open regionalism strategy in LA, which would make the region more competitive in international markets and would foster economic growth.

Therefore, it is important to analyze the factors that motivate LA countries to sign trade integration agreements with other countries or to enhance them. This research question is particularly interesting in a region where institutional and political factors are key determinants of regional integration. As the international context faces a potential reversal in terms of the breadth and scope of economic integration, we might see the LA experience as a harbinger of future events in other regions.

To analyze economic integration and the heterogeneity of trade agreements signed by LA countries, we considered four levels of economic integration: (1) shallow economic integration - non preferential trade agreement, preferential trade agreements, (2) deep economic integration - free trade agreements, and custom unions. We first analyzed the likelihood that pairs of countries sign an EIA or enhance existing EIAs. Second, we investigated heterogeneity in LA trade agreements in terms of institutional design and legal enforceability.

The results proved that institutional and political factors influence economic integration in LA. Traditional geographic and economic, institutional, and political factors play a role in the institutional quality of LA trade agreements. Empirical evidence also showed the impact of two exogenous political issues that affected foreign affairs in several countries on LA economic integration: the terrorist attack of September 11, 2001, 
and policy affinity with the Revolución Bolivariana.

Interestingly, the revitalized open regionalism strategy proposed by Bown et al. (2017) implies exploiting complementarities between LA regionalism and economic integration with the rest of the world. Natural question arises, "how can we predict the reversal of trade agreements?" We leave this as a relevant issue for future research.

Received 15 June 2017, Revised 2 July 2017, Accepted 31 July 2017

\footnotetext{
*Acknowledgements: The authors gratefully acknowledge the support and collaboration of SECYT, Universidad Nacional de Córdoba, and Generalitat Valenciana (SECYT 05/E349; PROMETEOII/2014/053). The authors thank Maria Victoria Barone, Pedro Degiovanni, and German Gonzalez for their participation in database processing. We would also like to thank the following for their helpful comments and suggestions: Maryan Naghsh Nejad, Stephan Klasen, Marina Murat, Benedikt Heid, Arne Klau, Adriana Espejo Sanchez, an anonymous member of the Editorial Board, one anonymous referee, and participants in the following international seminars: a) the one organized by the Centre for Economic and Regional Studies of the Hungarian Academy of Sciences in Budapest (June 2016); b) the MACIE Research Seminar at the Philipps-Universität Marburg (June 2015); c) the XXIX Jornadas Anuales de Economía del Banco Central del Uruguay held in Montevideo (August 2014); d) the 16th annual conference of the European Trade Study Group (ETSG) held in Munich (September 2014); and e) the Arnoldshain XII held in Valencia (September 2014).
} 


\section{References}

Allegret, Jean-Pierre, and Alain Sand-Zantman. "Monetary integration issues in Latin America: A multivariate assessment.” Panoeconomicus 55 (2008): 279-308.

Baier, Scott L., and Jeffrey H. Bergstrand. "Economic determinants of free trade agreements." Journal of International Economics 64 (2004): 29-63.

Bown, Chad P., Daniel Lederman, Samuel Pienknagura, and Raymond Robertson. Better Neighbors: Toward a Renewal of Economic Integration in Latin America. Latin America and Caribbean Studies; Washington, DC: World Bank, (2017).

Chisik, Richard. "Gradualism in free trade agreements: a theoretical justification." Journal of International Economics 59 (2003): 367-397.

Doctor, Mahrukh. "Why Bother With Inter $\square$ Regionalism? Negotiations for a European Union-Mercosur Agreement." Journal of Common Market Studies 45(2007): 281-314.

Feenstra, Robert C., Robert E. Lipsey, Haiyan Deng, Alyson C. Ma, and Hengyong Mo. "World Trade Flows: 1962-2000.” NBER Working Paper 11040 (2005).

Florensa, Luis M., Laura Márquez-Ramos, and María Luisa Recalde. "The effect of economic integration and institutional quality of trade agreements on trade margins: evidence for Latin America." Review of World Economics 151 (2015): 329-351.

Florensa, Luis M., Laura Márquez-Ramos, María L. Recalde, and Pedro Degiovanni. "Determinantes de la integración económica en Latinoamérica.” Estudios Económicos (2017), forthcoming.

García de la Cruz, José M., and Ángeles Sánchez Díez. “América Latina: ¿Volver a empezar?" Revista de Economía Mundial 18 (2008): 93-103.

Grugel, Jean B. "New Regionalism and Modes of Governance -- Comparing US and EU Strategies in Latin America." European Journal of International Relations 10 (2004): 603-626. 
Kohl, Tristan, Steven Brakman, and Harry Garretsen. "Do Trade Agreements Stimulate International Trade Differently? Evidence from 296 Trade Agreements." The World Economy 39 (2016): 97-131.

Magee, Christopher S. "Endogenous Preferential Trade Agreements: An Empirical Analysis.” The B.E. Journal of Economic Analysis \& Policy 2 (2003): 1-19.

Malamud, Andrés, and Philippe C. Schmitter. "La experiencia de integración europea y el potencial de integración del Mercosur.” Desarrollo Económico 46 (2006): 3-31.

Mansfield, Edward D., Helen V. Milner, and B. Peter Rosendorff. "Why democracies cooperate more: electoral control and international trade agreements." International Organization 56 (2002): 477-513.

Márquez-Ramos, Laura. "Regionalism, subnational variation and gravity: A fourcountry tale.” Investigaciones Regionales 35 (2016): 7-36.

Márquez-Ramos, Laura, Inmaculada Martínez-Zarzoso, and Celestino SuárezBurguet. "Determinants of Deep Integration: Examining Socio-political Factors." Open Economies Review 22 (2011): 479-500.

Márquez-Ramos, Laura, Luis Marcelo Florensa, and María Luisa Recalde. "Economic Integration Effects on Trade Margins: Sectoral Evidence from Latin America." Journal of Economic Integration 30 (2015): 269-299.

Marshall, Monty G., and Keith Jaggers. "Polity IV Project: Dataset Users' Manual." (2002).

McNally, Christopher A. "The challenge of refurbished state capitalism: Implications for the global political economic order." DMS - Der moderne Staat 6 (2013): 33-48.

Molina, José Enrique. "Izquierda y estabilidad de la democracia en América Latina: La ideología de la Revolución Bolivariana y su repercusión sobre el proceso político en Venezuela y América Latina.” América Latina Hoy 35 (2003): 169-198.

Nelson, Marcel. "Institutional Conflict and the Bolivarian Revolution: Venezuela's Negotiation of the Free Trade Area of the Americas." Latin American Perspectives 40 
(2013): 169-183.

Orefice, Gianluca, and Nadia Rocha. "Deep Integration and Production Networks: An Empirical Analysis." The World Economy 37 (2014): 106-136.

Peña, Félix. "Es posible una visión realista pero positiva de la integración latinoamericana y del Mercosur?" http://www.felixpena.com.ar, (2010).

Peña, Félix. "Integración regional e inserción internacional de América Latina en un mundo de múltiples opciones.” http://www.felixpena.com.ar, (2011).

Schmitter, Philippe C. "Central American Integration: Spill-Over, Spill-Around or Encapsulation?" Journal of Common Market Studies 9 (1970): 1-48.

Stephen, Matthew D. "Rising powers, global capitalism and liberal global governance: A historical materialist account of the BRICs challenge." European Journal of International Relations 20 (2014): 912-938.

The Bello Column. "No Brussels here. How Latin America may prosper from a different kind of integration." The Economist, July 7, 2016.

The Bello Column. "There has never been a better time for Latin American integration." The Economist, March 23, 2017.

Vicard, Vincent. "Trade, conflict, and political integration: Explaining the heterogeneity of regional trade agreements." European Economic Review 56 (2012): 54-71.

Wyplosz, Charles. "Deep Economic Integration: is Europe a Blueprint?" Asian Economic Policy Review 1 (2006): 259-279. 


\begin{tabular}{|c|c|c|c|c|c|c|c|c|c|}
\hline 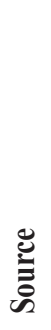 & 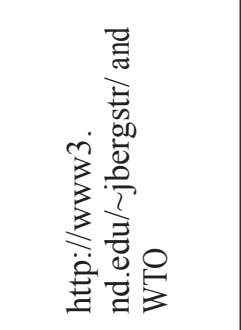 &  &  &  & 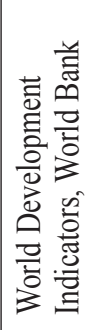 & 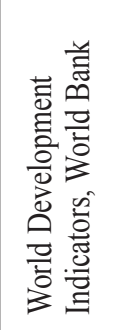 & $\begin{array}{l}\text { 氙 } \\
\text { 穵 }\end{array}$ & $\begin{array}{l}\text { 氙 } \\
\text { 穵 }\end{array}$ & $\underset{\text { 穵 }}{\bar{U}}$ \\
\hline  & 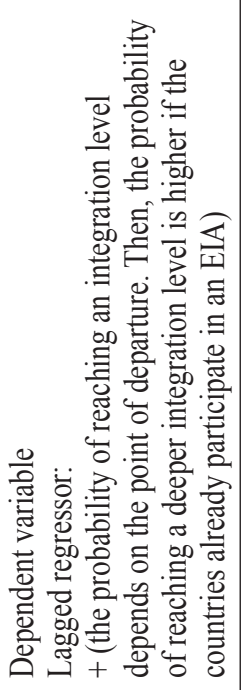 & 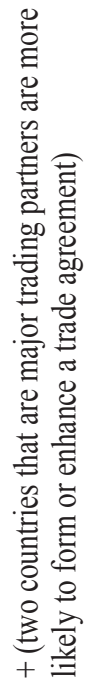 &  & 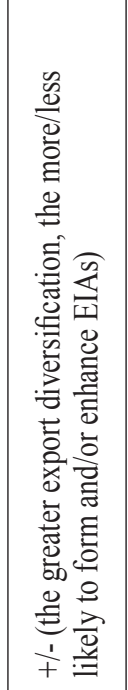 & 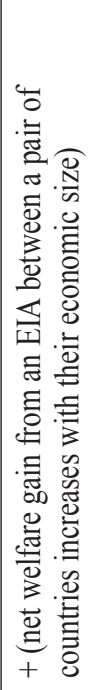 & 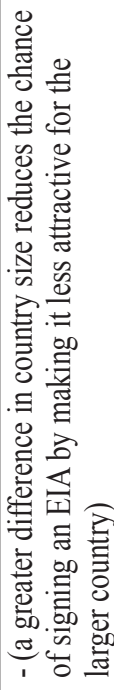 & 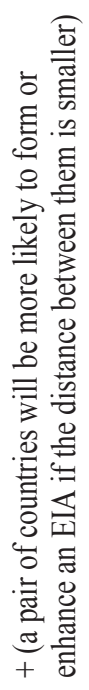 & 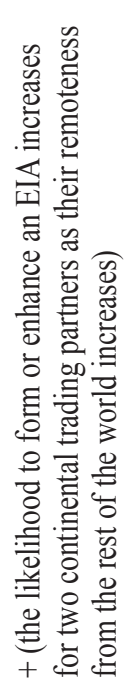 & 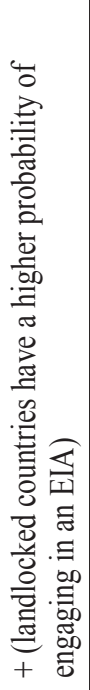 \\
\hline .气 &  & 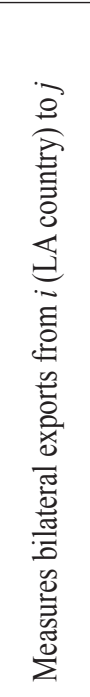 & 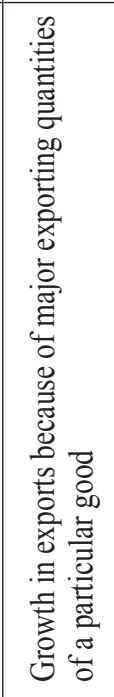 & 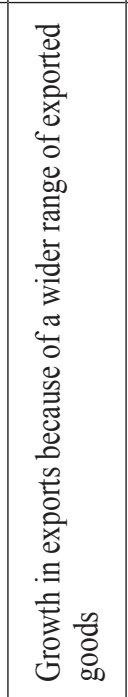 & 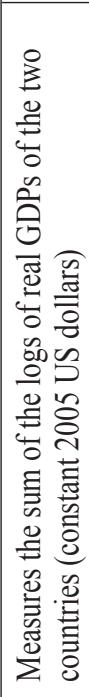 & 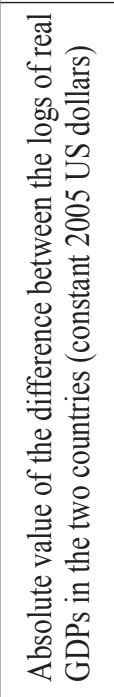 & 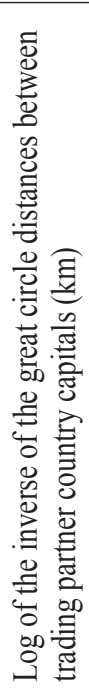 & 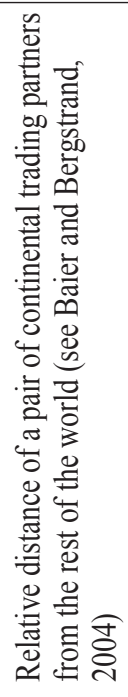 &  \\
\hline 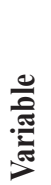 & 죄 & 胥 & 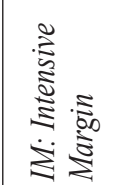 & 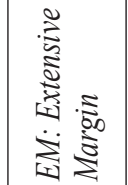 & ¿্ড & $\approx$ & $\underset{z}{\frac{2}{z}}$ & $\underset{1}{\stackrel{2}{2}}$ & 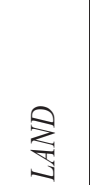 \\
\hline
\end{tabular}




\begin{tabular}{|c|c|c|c|c|c|c|c|c|}
\hline 异 & $\underset{\text { 矛 }}{=}$ & 空 &  & 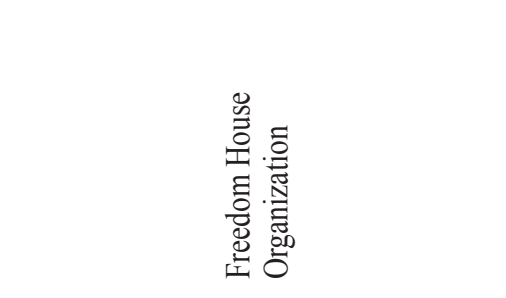 & 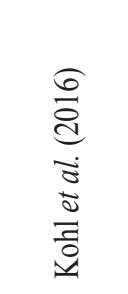 & 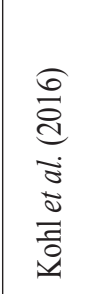 & 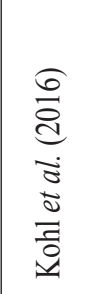 & 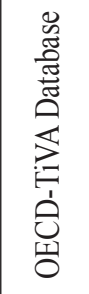 \\
\hline  & 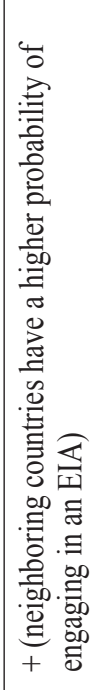 & 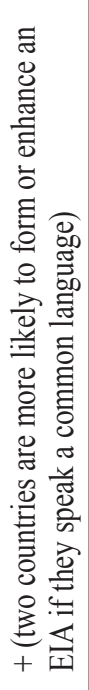 & 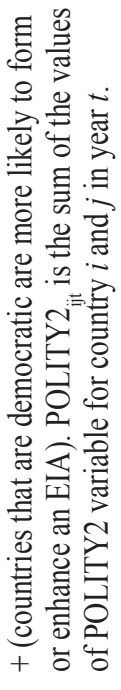 & 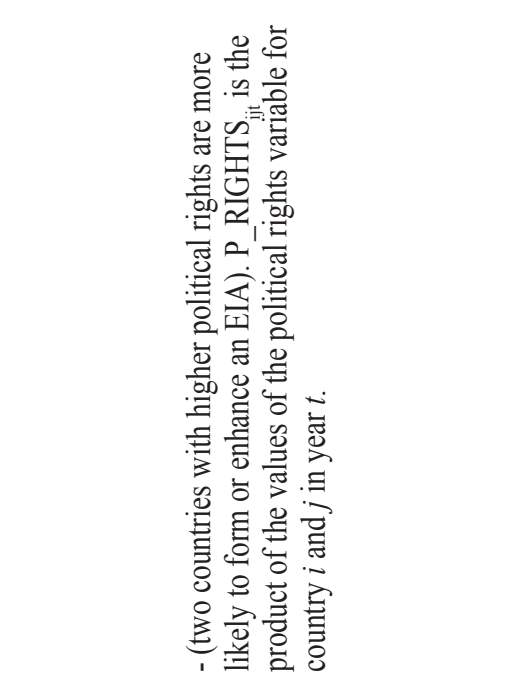 & 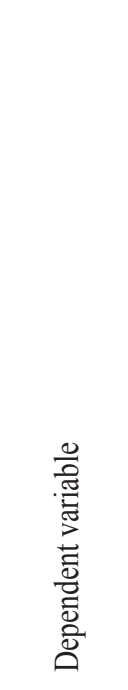 & 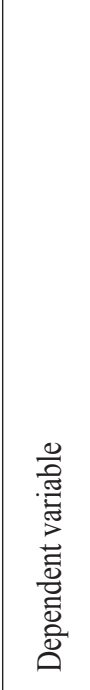 & 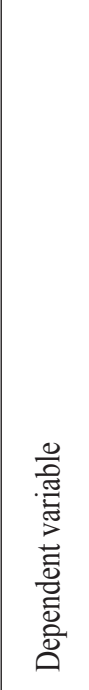 & 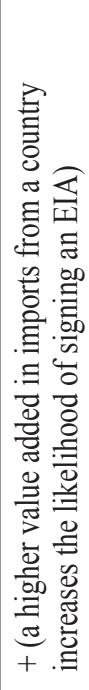 \\
\hline 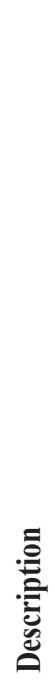 &  & 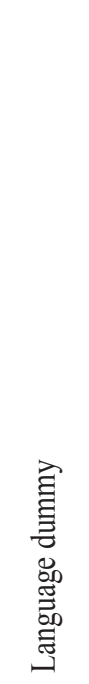 & 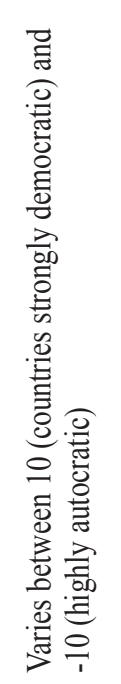 & 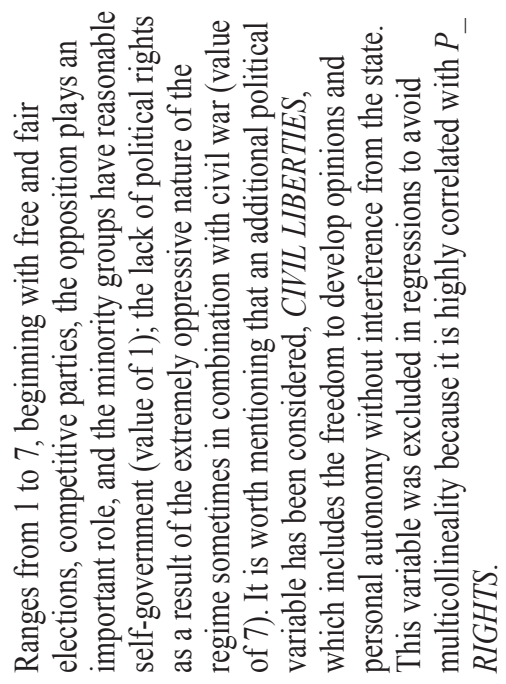 &  & 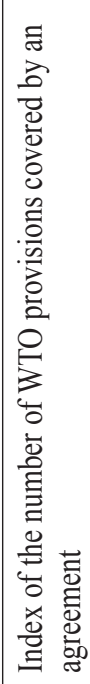 &  & 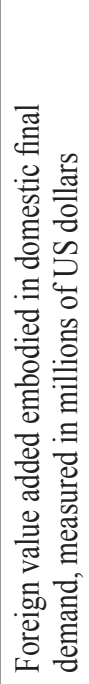 \\
\hline $\overrightarrow{\overline{\underline{\pi}}}$ & ₹ & $\underset{\exists}{3}$ &  & 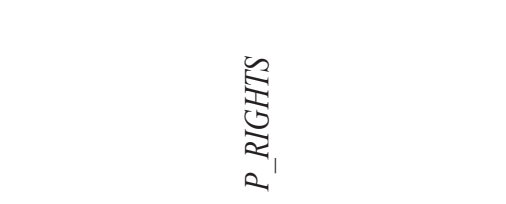 & $\approx$ & 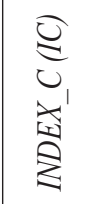 & 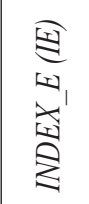 & $=$ \\
\hline
\end{tabular}

